IZA DP No. 8785

Seriously Strengthening the Tax-Benefit Link

Pedro Portugal

Pedro S. Raposo

January 2015

Forschungsinstitut zur Zukunft der Arbeit Institute for the Study of Labor 


\title{
Seriously Strengthening the Tax-Benefit Link
}

\author{
Pedro Portugal \\ Banco de Portugal, \\ Universidade NOVA de Lisboa and IZA \\ Pedro S. Raposo \\ UCP - Catolica Lisbon School of Business and Economics
}
Discussion Paper No. 8785
January 2015

IZA
P.O. Box 7240
53072 Bonn
Germany

Phone: +49-228-3894-0

Fax: +49-228-3894-180

E-mail: iza@iza.org

Any opinions expressed here are those of the author(s) and not those of IZA. Research published in this series may include views on policy, but the institute itself takes no institutional policy positions. The IZA research network is committed to the IZA Guiding Principles of Research Integrity.

The Institute for the Study of Labor (IZA) in Bonn is a local and virtual international research center and a place of communication between science, politics and business. IZA is an independent nonprofit organization supported by Deutsche Post Foundation. The center is associated with the University of Bonn and offers a stimulating research environment through its international network, workshops and conferences, data service, project support, research visits and doctoral program. IZA engages in (i) original and internationally competitive research in all fields of labor economics, (ii) development of policy concepts, and (iii) dissemination of research results and concepts to the interested public.

IZA Discussion Papers often represent preliminary work and are circulated to encourage discussion. Citation of such a paper should account for its provisional character. A revised version may be available directly from the author. 
IZA Discussion Paper No. 8785

January 2015

\section{ABSTRACT}

\section{Seriously Strengthening the Tax-Benefit Link}

On January 1st 1994 Portugal introduced, for the first time, inflation indexation in the old-age pension formula. This change considerably decreased the uncertainty regarding the perception of the link between the stream of labor earnings and future pensions. The effect of indexation was large and, by itself, increased the expected pension amount by $28 \%$ in real terms. Individuals appear to have reacted to the policy change: labor earnings increase significantly during the eligible years approaching retirement age.

JEL Classification: J14, J26, J31

Keywords: pension policy reform, hours, earnings, tax-benefit link

Corresponding author:

Pedro S. Raposo

UCP - Catolica Lisbon School of Business and Economics

Palma de Cima

1649-023 Lisboa

Portugal

E-mail: pedro.raposo@ucp.pt

\footnotetext{
* The authors are grateful for helpful comments and suggestions from Jan van Ours and José Varejão. Pedro S. Raposo gratefully acknowledges financial support from the Portuguese Foundation of Science and Technology, FCT [SFRH/BD/21906/2005]. Part of this work was carried out while he was visiting the Bank of Portugal, whose support is gratefully acknowledged. We are grateful to the Portuguese Ministry of Employment for access to the data and thank Lucena Vieira for outstanding data and computational assistance.
} 


\section{Introduction}

A critical aspect in the discussion of the social security reform is whether individuals respond to the link between the social security taxes they pay and the retirement benefits they receive. The reaction of individuals to this link is influenced by the way they envision the future stream of benefits.

Feldstein (2005) argued that social security should be redesigned, strengthening the tax payers' perceptions of the link between taxes paid and future benefits, which is to say, by increasing the tax-benefit link. This might ameliorate the adverse effect that the public pension system has on working incentives. With an improvement of the tax-benefit link individuals understand more clearly that it is worth saving for retirement. In a social security context, a change in one's current earnings may represent an increase in one's future pension earnings. Once they perceive the link, workers might react to it.

The reform of the social security system that was introduced in Portugal on January 1st 1994 provides us exceptional conditions to evaluate the impact of a significant change of link between the taxes paid and the expectation of amount of pensions to be collected in the future. A critical element of this reform, one that substantially decreased the uncertainty regarding the definition of future pensions (by at least a half, in terms of the mean square errors of predicted pensions), was the inflation indexation of social security contributions that were eligible for the formation of pensions. Thus, from January 1st, 1994 onward the reference earnings became the best 10 real (deflated) yearly earnings out of the last 15 years, ruling out the previous formula in which the pension was determined by the best 5 nominal yearly earnings out of the last 10 years. ${ }^{1}$

The new formula is actuarially fairer than the previous one, in the sense that it closed the gap between what people paid to what they would receive. An important implication of this change was that it not only reinforced the link between contributions and benefits, but also made the social security system considerably more generous, increasing the average pension by 28 percent in real terms, simply as a consequence of indexation. Since under the new law an individual's perception of the link between current earnings and future pension is much clearer, one may expect a better command over the age-earnings profile, one in which the worker is aware of the relationship between that profile and the determination of his pension.

The contribution of this study to the literature is twofold. First, given the richness of information in the matched employer-employee dataset (Quadros de Pessoal), one can straightforwardly characterize the impact of the policy change on the definition of the pensions. Thus, for each worker it is possible to estimate his future pension. This calculation can be computed for both the pre- and post-reform period, providing us a clear picture of the empirical dis-

\footnotetext{
${ }^{1}$ The number of years of contributions necessary to obtain a full pension also increased from 36 to 40 years.
} 
tributions of the pensions over the two periods. And second, we should be able to disentangle the differences of the earning profiles as the workers approach retirement age, over the two distinct pension regimes. More specifically, in the present work we will assess whether individuals reacted to this change in policy by increasing their work effort, measured in terms of hours worked and labor earnings collected.

We take advantage of the characteristics of the Portuguese pension system, together with the matched employer-employee nature of the dataset, to design our identification strategy in a way that allows us to analyze this reform in a quasi-experimental setting: first, one identifies a clear group of affected individuals (the treatment group); second, one observes different intensities of impact of the policy change during the final years prior to retirement; and third, one can also follow a group of non-affected individuals (comparison group). For this last case, prime-age workers are used to control for a general (aggregate) trend in wages over the sample period.

The structure of the remainder of the article is as follows. In Section 2 a brief review of literature is given. Section 3 summarizes the institutional setting in Portugal, in terms of both social security and wage setting. Section 4 provides a description of the data used, and Section 5 presents the analysis of the effects on the pension distribution. Section 6 includes discussions of how individuals reacted at the intensive margin. Section 7 concludes.

\section{Earlier literature}

In the study by Dominitz et al. (2003) the authors performed an intensive faceto-face survey to study how Americans perceive their benefits. They found substantial uncertainty and heterogeneity of beliefs. In general, however, individuals expect that the benefits level will not be reduced, even if some prefer to save through a private pension plan (Boeri et al. (2001)). Chan and Stevens (2008) used self-reported, employer reported, and Social Security Administrative data from the health and retirement study (HRS) to examine the relationship between the knowledge of retirement benefits and the individual response to those benefits. They found that individuals well-informed about their own pension plans are more responsive to pension incentives than the average individual. Feldstein (2005) favors an architecture of social security that strengthens the tax payers' perception of the link between taxes paid and future benefits.

Even if the tax-benefit link is perceived, individuals may not react to it, not because they do not see it, but because of specific behavioral reasons. Saving theory assumes that individuals are able to solve the optimization problem and it presumes that they have the necessary self-control to execute the optimal problem (Benartzi and Thaler (2007)). According to O'Donoghue and Rabin (2001), saving for retirement is very important, but procrastination leads indi- 
viduals to do a very poor job at it. It is argued that they underweight outcomes in the distant future and overweight outcomes in the near future. (Lynch Jr. and Zauberman (2006)). Madrian and Shea (2001) analyze the 401K saving in the U.S. and find that the slope of the saving gradient with respect to age is positive, meaning that individuals postpone their decision to start saving for retirement, but once they start saving, they save at an increasing rate.

A branch of the empirical literature has focused on the impact of social security on labor supply, at both the extensive margin and the intensive margin. At the extensive margin, Gruber and Wise (2004) and Blöndal and Scarpetta (1999) suggest that in many countries pay-as-you-go systems generated a significant decrease in labor force participation among older workers. To analyze this phenomenon, Disney (2004) splits the pension contribution into a tax component and an actuarial (forced saving) component. He applies several within and across generation indicators to 22 OECD countries over selected time periods $(1961,1975,1997)$. The results suggest that it is only the tax component of the contribution that tends to distort the employment decision. Fisher and Keuschnigg (2010) develop a model based on a pay-as-you-go system with taxbenefit link to investigate how pension reform might affect labor supply. They find that reforms that increased the tax-benefit link tend to stimulate labor supply at both the intensive and extensive margins.

Disney and Smith (2002) explore the abolishment, in 1989, of the earnings rule in the United Kingdom, using data from the Family Expenditure Survey from April 1984 to March 1994. According to the earnings rule, the basic pension was withdrawn at 50 pence per $£$ of earnings from $£ 75$ up to $£ 79$, and one $£$ for one $£$ thereafter. They explore the reform as a quasi-experiment, comparing changes in hours of men aged 65-69 and those of women aged 6064 , before and after the reform. According to the authors, in reaction to the abolition of the earnings rule, older male participants raised their working hours by around four hours per week. They find a smaller effect for women (two hours).

Keuschnigg and Keuschnigg (2004) calibrated a general equilibrium with overlapping generations model, using data from the Austrian social security. Austria has increased the pension calculation reference period from the five highest earnings years, to the entire earnings history. The authors found that this change in policy had produced strong labor market effects. In particular, they conclude that workers increased their supply of hours by $4 \%$.

Liebman et al. (2009) use U.S. data for individuals born in 1931 and 1941 taken from the Health and Retirement Study longitudinal survey linked to Social Security earnings records. They explore discontinuities created by changes in the benefit rules, and found evidence of an increase in the elasticity of hours with respect to the net-of-tax share of 0.42. They did not find, however, any significant relationship on the earnings elasticity with respect to the net-of-tax share. 


\section{Institutional context}

\subsection{Social security in Portugal}

Social security in Portugal covers most of the employees in the private sector, including agricultural workers, the self-employed, and domestic help, and it is based on a pay-as-you-go system, in which current contributions are used to pay current pensions. Retirement is organized in a defined benefit system, that entitles the individual to a monthly pension calculated on accrued seniority at retirement, which is a weighted average of the labor earnings throughout a period in the person's working years.

In the general scheme, the employee pays a contributory rate of $11 \%$ of the gross wage, while the employer pays $23.75 \%$. This contribution, in the form of a tax, entitles individuals to retirement, survivor, and disability pensions, as well as unemployment, health insurance, maternity, or paternity leave benefits.

Since 1984 and until 1993 the statutory retirement age was 65 for men and 62 for women, and the reference earnings to calculate the pension were the best 5 (nominal) yearly earnings out of the last 10 years. Following retirement, pensions were linked into inflation. The minimum entitlement contributory period was 10 years. Full retirement pension was only obtained after 36 years of contributive payments.

\subsection{The reform of the old-age pension system}

A social security reform was implemented in Portugal (Decreto-Lei 329/93) with the goal of increasing the link between taxes and benefits. The 1993 law increased women's statutory retirement age from 62 to 65 years, raised the minimum entitlement contributory period from 10 to 15 years, changed from inflation non-indexed earnings based to inflation indexed pensions earnings based and changed the full old-age pension entitlement period from 36 to 40 years of contributive payments. ${ }^{2}$ This law defined that from January 1st 1994 on, the reference earnings for the calculation of the pension took effect.

In the pre-reform period the reference earnings were the 5 highest annual labor earnings (in nominal terms) out of the last 10. The pension was calculated as $P=W \times 2.2 \% \times N$, where $\mathrm{P}$ is the pension, $\mathrm{W}$ is the reference earnings (in nominal terms), and $\mathrm{N}$ is the number of years of contributions to the system, which was at least 36 for a full pension. The reference earnings were computed as the average earnings received in the eligible period.

Thus, in the post-reform period, the reference earnings became the highest 10 annual labor earnings (in real terms) out of the last 15 . The pension was calculated as $P=W_{R} \times 2 \% \times N$, where $\mathrm{P}$ is the pension, $W_{R}$ is the reference

\footnotetext{
${ }^{2}$ The retirement age for women increased by six months every year, until it converged in 1999 to the level of men. See Martins et al. (2009) for details on the impact of this particular reform.
} 
earnings (in real terms) and $\mathrm{N}$ is the number of years of contributions to the system, which was at least 40 for a full pension. The reference earnings are computed as the average earnings received in the eligible period.

This new formula was implemented fully and immediately, which means that there was no transitory period. Benefit rules changed in an actuarial direction, while maintaining a pay-as-you-go system.

As mentioned above, in the pre-reform period, the reference earnings are the highest 5 annual nominal labor earnings out of the last 10 . We call this period the pre-reform eligible period, and to the period corresponding to the worst 5 the pre-reform non-eligible period, meaning that the worst years are not used when calculating the pension. In the post-reform period the reference earnings are the highest 10 annual real labor earnings out of the last 15 . We call the period corresponding to the best 10 years before retirement the postreform eligible period, and to the period corresponding to the worst earnings the post-reform non-eligible period. The reference earnings are computed as the average earnings received during those eligible periods.

Figure 1: Set-up of the analysis: Policy Illustration

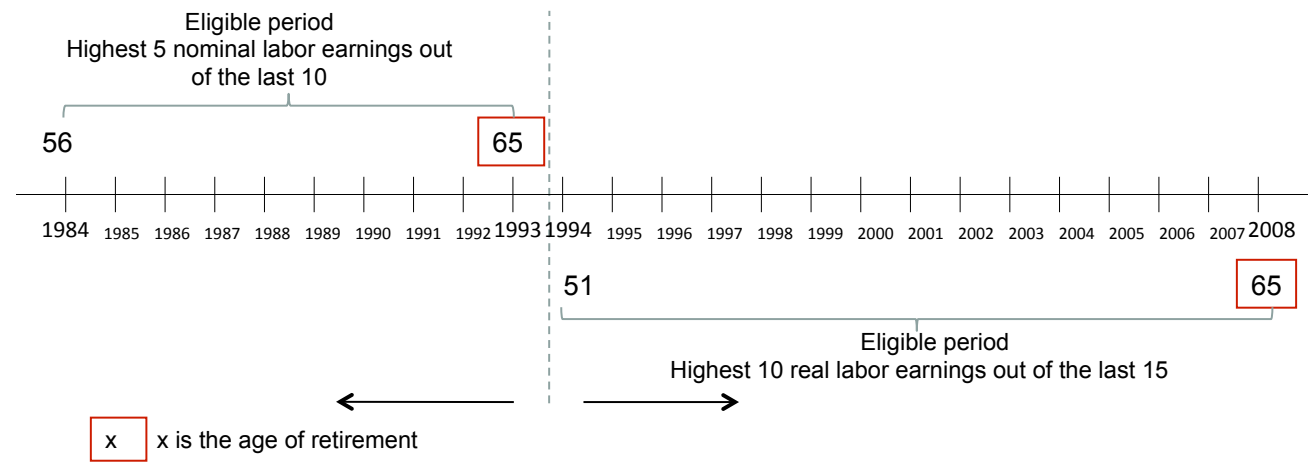

Notes: This figure illustrates the pension policy. An individual that retires in 1993 is entitled to a pension that is calculated from the highest 5 nominal annual labor earnings out of the last 10 . In the post-reform period, meaning after 1993, an individual that retires in 2008 is entitled to a pension that is calculated from the highest 10 real annual labor earnings out of the last 15 . In the sample the retirement age varies between 55 and 65 years old.

Figure 1 provides a representation of the rules behind the analysis design. For a typical individual, who retires at the age of 65 in 1993, the eligible period would be the highest 5 annual nominal labor earnings between 1984 and 1993, and the non-eligible period would be the lowest 5 annual nominal labor earnings in the same last 10 years prior to retirement. 


\section{Data}

In this study a longitudinal data set matching firms and workers in the Portuguese economy, called Quadros de Pessoal (QP - "Lists of Personnel") is used for the period 1984 until 2008. The data are gathered annually by the Ministry of Employment based on an inquiry that every establishment with wage-earners is obliged by law to fill in. Reported data cover all the personnel working for the establishment with at least one wage earner in a reference month (in March until 1993, and in October from 1994 on) ${ }^{3}$. Currently QP gathers information on more than 300,000 firms and 3 million workers. Given the mandatory nature of the survey plus the fact that these data cover all wage earners in the private sector, problems commonly associated with panel data sets, such as panel attrition, are considerably attenuated.

Reported data on the worker side include gender, age, schooling, monthly earnings (split into several components): base wages, regular bonus payments (e.g., seniority), non-regular benefits (profits distribution and bonus premia), and overtime payments. The information on earnings is reported by the employer, which is known to be subject to less measurement error than workerprovided earnings data. The firm data include information on region, industry, shipments, and size. A worker identification code based on a transformation of the social security number enables tracking him over time. In the current study the data set is limited to the population of male workers that are fulltime wage earners in the private non-farm sector who retire between 55 and 65 years old. A worker is considered to be retired if he is over 55 years old, leaves the sample, and does not return to the database. Female workers are excluded, as they were subject to other policy changes.

There are specific constraints pertaining to the surveys that must be mentioned. QP is available from 1984 on, which means there are only 10 years of data available before the new law was implemented. In order to avoid contamination of the sampling plan with the effects of the legislation existing prior to the 1993 law, we consider a post-reform period that is observed entirely after 1993. Since this law establishes a 15 year period of reference earnings for the calculation of the pension in the post-reform period, we select individuals who retired in the year 2008 .

We consider several measures of earnings as outcome variables. The outcome variables are real earnings, real base wage, real total earnings, real hourly earnings, and total hours. Hourly earnings are computed as the ratio of total earnings to total number of hours. Total number of hours is the sum of normal hours and overtime hours. All earnings variables were deflated using the Consumer Price Index (see Appendix A for details). ${ }^{4}$

\footnotetext{
${ }^{3}$ See Cardoso(2006) for more details.

${ }^{4}$ Appendix B gives a table with a summary of statistics of the key variables in the data set.
} 


\section{The impact of the reform on the pension system}

In order to calculate the impact of the policy change on the social security system we look into the pension distribution calculated under both regimes. First, we compute the monthly pensions of individuals retiring in 1993 using the pre-reform rules. Second, we calculate the monthly pensions of individuals retiring in 2008 using the post-reform rules.

Table 1: Monthly pensions summary statistics

\begin{tabular}{lccc} 
& $\begin{array}{c}\text { Pre-reform } \\
(1984-1993)\end{array}$ & $\begin{array}{c}\text { Post-reform } \\
(1994-2008)\end{array}$ & $\begin{array}{c}\Delta \\
(\%)\end{array}$ \\
\hline Mean & 565 & 912 & 61 \\
Coefficient of variation & 0.63 & 0.59 & \\
P10 & 288 & 437 & 52 \\
P25 & 355 & 512 & 44 \\
P50 & 454 & 674 & 48 \\
P75 & 621 & 976 & 57 \\
P90 & 944 & 1633 & 73 \\
Minimum wage & 376 & 426 & 13 \\
No. observations & 7309 & 16023 & \\
\hline
\end{tabular}

Notes: This table shows summary statistics of pension values calculated according to the pre-reform rules and post-reform rules. In the pre-reform, pensions are calculated using individuals that retire in 1993 and in the post-reform, pensions are calculated using individuals that retire in 2008. Numbers are in euros (deflated using 2008 as base year). The last line is the average legal minimum wage in euros (deflated using 2008 as base year). The last column shows the growth between pre- and post-reform $(\%)$.

Table 1 provides the summary statistics of pension values. An individual retiring in 1993 would expect on average a pension of 565 euros. An individual retiring in 2008 would expect on average a pension of 912 euros. Results exhibit an increase in the amount of pensions along the entire distribution. The shift in the distribution affected all quantiles, from the lowest pension values to the individuals who would be entitled to the highest pensions. This shift means a very significant increase of around 61 per cent on average. The increase is higher on the right tail of the distribution. Figure 2 plots the simulated pension distributions summarized above. The distribution shifts clearly to the right. This represents a sizable increase in the values of pensions for the social security pension system.

These results do not reflect solely the policy change because they include the overall wage trend over this period. There is a 15 year time window between the post-reform observations and the pre-reform observations. One would expect that the overall wage level increased in 15 years. Thus, in order to identify the effects of this policy change, it is necessary to offset the wage trends throughout 


\section{Figure 2: Pensions distribution - Simulation using pre- and post- reform rules}

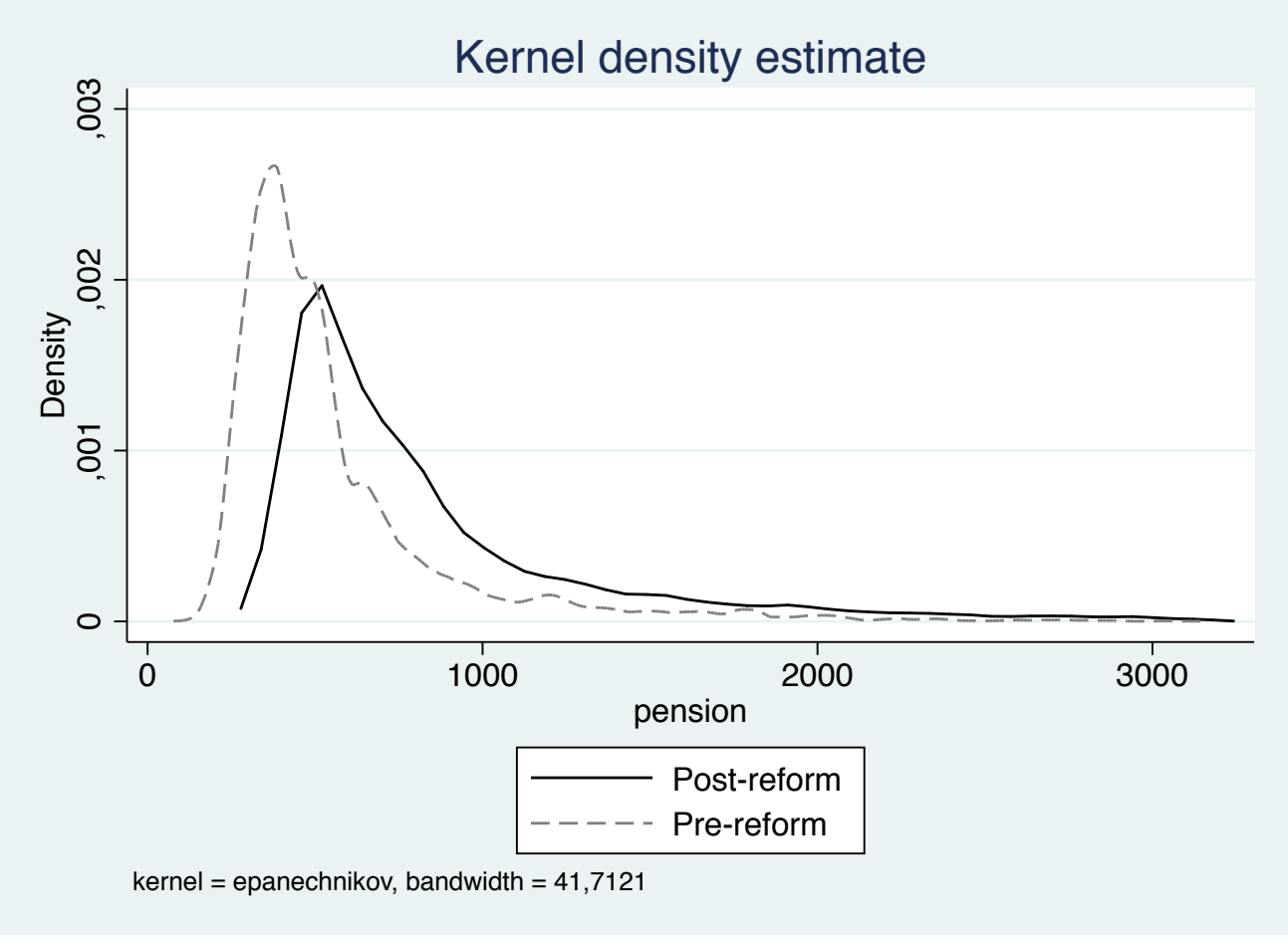

Notes: This figure shows the distributions for pensions calculated according to the pre-reform and the post-reform rules. Pre-reform distribution represents the computed pensions for individuals retiring in 1993. Post-reform distribution represents the computed pensions for individuals retiring in 2008.

the period.

In order to properly decompose the effects of this policy change, from this point on we will focus the analysis solely on individuals who retired in $2008 .^{5}$ We thus calculate the indexation effect and the period effect, by applying prereform rules and post reform rules. In other words, we simulate both pension regimes using the wage distributions that prevailed until $2008 .{ }^{6}$ Table 2 presents the results of the decomposition exercise using information from individuals retiring in 2008. The total policy effect on the mean pension is computed to be $28 \%$ (computed as -3 plus $31 \%$ or, identically, -1 plus $29 \%$ ). Column (a) represents the mean pensions using the pre-reform reference period (highest 5 out of 10) and column (b) represents the mean pensions using the post-reform reference period (highest 10 out of 15). In line (1) we use non-

\footnotetext{
${ }^{5}$ This allows us to use their information in either a 10 or 15 year reference period window without contaminating the sample plan with the ruling of 1993.

${ }^{6}$ This is not trouble free. The 2008 wage distribution may have changed due to the pension law, as will be shown below.
} 
indexed earnings as reference earnings and in line (2) we use indexed earnings as reference earnings. In line (3) we compute the difference between the level of pensions using the non-indexation (line (1)) and the indexation (line (2)) criteria. This provides a measure of the indexation effect. The indexation effect can be computed in two ways (using column (a) or column (b)). Regardless of the decomposition, the indexation effect is very large in both decompositions, $29 \%$ and $31 \%$, respectively.

Table 2: Simulation of the two pension regimes

\begin{tabular}{lcccc} 
& & $\begin{array}{c}1999-2008 \\
\text { Pre-reform } \\
\text { reference period }\end{array}$ & $\begin{array}{c}\text { 1994-2008 } \\
\text { Post-reform } \\
\text { reference period }\end{array}$ & Period effect \\
& & $(\mathrm{a})$ & $(\mathrm{b})$ & $\%(\mathrm{c})=\frac{(b)-(a)}{(a)}$ \\
\hline Non-indexation & $(1)$ & 716 & 696 & -3 \\
Indexation & $(2)$ & 921 & $(0.72)$ & -1 \\
& & $(0.62)$ & $(0.59)$ & \\
Indexation effect & $\%(3)=\frac{(2)-(1)}{(1)}$ & 29 & 31 & \\
\hline
\end{tabular}

Notes: a) This table shows the simulated values for the mean pension according to four different rules which allows decomposing the reform effect into an inflation indexation and a period effect. The decomposition is done using information from individuals that retired in 2008. b) Columns (a) and (b) represent the simulation of the pension using respectively the pre-reform (highest 5 out of the last 10) and post-reform reference period (highest 10 out of the last 15). Column (c) displays the percentage change between the two rules. c) Rows (1) and (2) represent the simulation of the pension using the non-indexation and indexation criteria to choose the eligible wages, respectively nominal and real values. Row (3) represents the simulated indexation effect which we computed as a percentage change in pensions moving from non-indexation to indexation rule. d) Standard deviation is in parentheses.

The last column in Table 2 shows the difference between columns (a) and (b) and represents the period effect. The period effect, that is, the change in the value of the pension implied by extending the reference period, accounts for a decrease of the pension mean of $-1 \%$ or $-3 \%$. Thus, the indexation effect is considerably more important in explaining the change of pension in 2008.

Overall, between 1993 and 2008, pensions increased 61\% on average. About half of this increase is generated by the overall wage trend during this period. Indexation explains almost all of the remaining $28 \%$ change.

Figure 3 shows the distribution of pensions in 2008 for the same decomposition exercise illustrated in Table 2. The increase of the pension mean is due mainly to the indexation effect. Using the post-reform reference period (black lines) the indexation curve has a clear shift to the right (positive and significant indexation effect) and there is no clear change in the shape of the distribution. Using the pre-reform reference period (grey lines), a positive and 
Figure 3: Pensions distribution - simulation

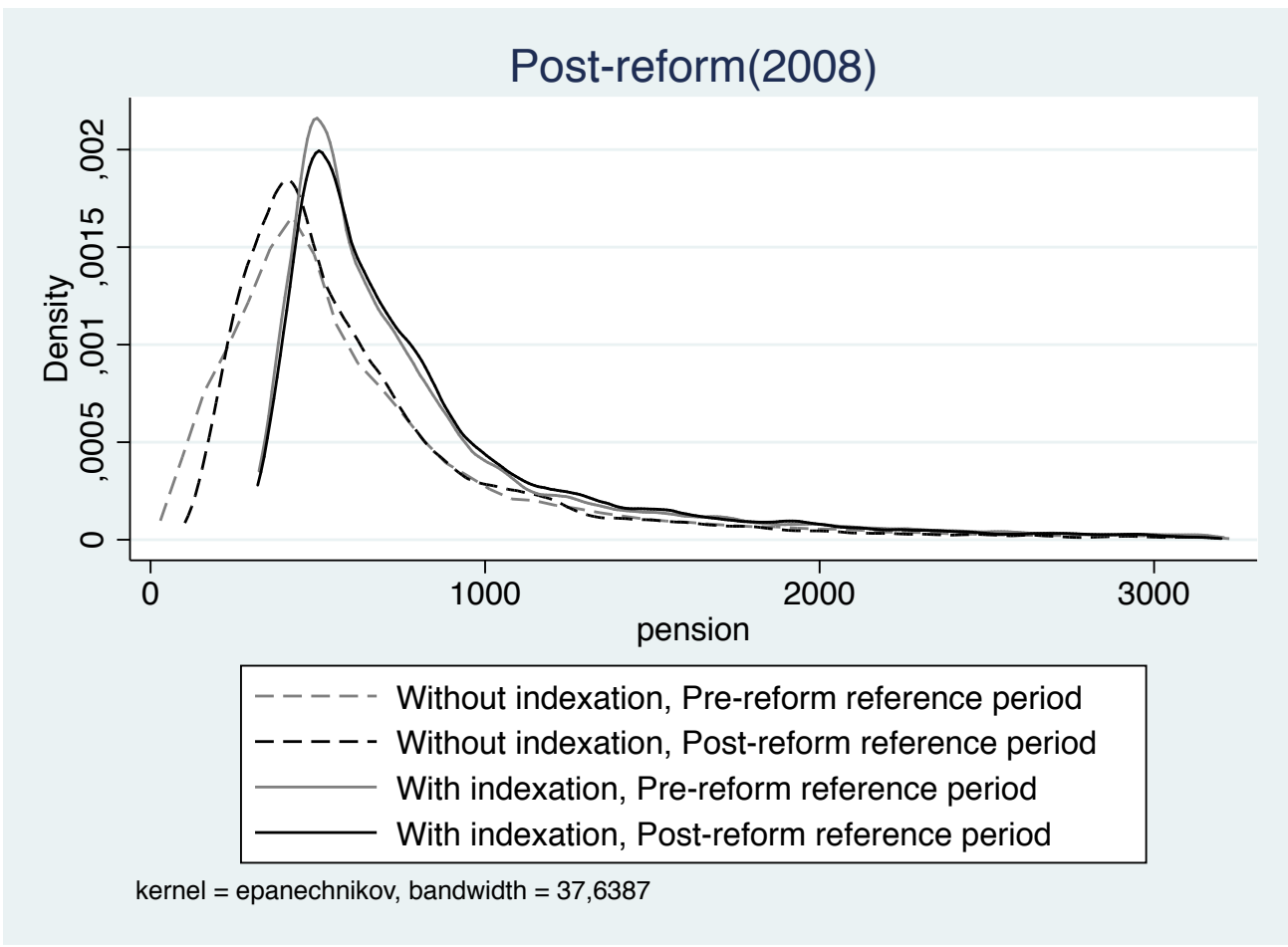

Notes: This figure shows the distributions for pensions calculated for individuals that retire in 2008 using the pre-reform and post-reform reference periods. Non-indexation and indexation criteria represent the computed pensions for individuals applying respectively the nominal earnings rule and the real earnings rule.

significant indexation effect is also observed. The change in the shape of the distribution of the pensions is also notable. It is clear that the 5 out of 10 rule generates a less dispersed pension distribution.

The indexation effect is represented in the shift between dashed and bold lines. The period effect is observable by comparing within the dashed or the bold lines, meaning that we are comparing the situation applying the pre-reform reference period with the situation where the pension calculation applies the post-reform reference period.

The period effect results are less clear-cut. The period effect moved the distribution slightly to the left while also slightly decreasing the dispersion around the mode. The results of the analysis clearly indicate that the indexation effect dominates. It moved the distribution to the right and it is the main element driving the decrease in the dispersion of the pension distribution. The coefficients of variation reported in Table 2 confirm that the decrease in the dispersion is due mainly to the indexation effect. Indexation made the amount of the pension significantly more predictable. One way to measure the reduc- 
tion in the uncertainty of the amount of the pension is to regress pensions on wages. The unexplained variance in the pre-reform period regression is 6479 and in the post-reform period it became 3290 . Thus, uncertainty was reduced by half.

In a nutshell, changing the reference period had a much lower impact than changing the indexation. The impact is clear not only at the mean, but also along the whole pension distribution. The period effect decreases dispersion and the indexation effect increases the mean of pensions and reduces even further the dispersion of pension values. ${ }^{7}$

\section{The time profile of earnings and hours adjustment prior to retirement}

In this section we address the following question: do workers react to changes in the tax-benefit link by increasing their labor earnings near the age of retirement?

In labor economics much attention has been given to the effects of the incentives at the workplace on the worker's effort. In this section we study the improvement of the tax benefit link as an incentive to increase earnings. In the context of this study there are at least three mechanisms enabling workers to obtain higher earnings at the end of their contributions career. First, a promotion scheme can be used as an incentive or reward to those individuals who perform well on a job. Suppose that the promotion premium or the promotion probability depends on the performance of the worker. By increasing effort, the kind that increases productivity, the worker is promoted. This in turn leads to higher earnings. Second, firms and workers have incentives to collude through a plan that would increase earnings in order to increase workers' pensions. ${ }^{8}$ This can be partly explained by selective attrition from employment (Boeri and Van Ours, 2008, p. 134). The most productive workers are most likely to be the last to retire, and the firm might thus collude with the workers as a way to compensate long-term high productivity and the dedication to the firm. In Portugal there is anecdotal evidence that some firms increase a worker's last year earnings (which, under the 1993 rules, represents $1 / 10$ of the pension) in order to increase the pension of the worker. Third, under a scheme of deferred compensation, workers are paid below their marginal productivity in the first years of the contract and then paid above it during the latter part of their career. This produces an earnings profile that is upward sloping with age. This differed scheme discourages workers from shirking and it self-selects matches in which both workers and firms seek to engage in long-term relationships. As a consequence of the improvement of the tax benefit link, such a plan would be

\footnotetext{
${ }^{7}$ The inflation rate was on average $13.5 \%$ and $3.1 \%$ respectively in the pre-reform period (1984-1993) and post-reform period (1994-2008).

${ }^{8}$ See (Lazear, 1998, p. 430) for collusion in the presence of portability on pension plans.
} 
interesting for both the worker and the firm. In this context, one would expect to observe an increase in earnings over the last working decade.

The 1993 reform offers a setting that allows for comparing workers that retired under the new policy system with workers that retired under the old pension system. The distinct factor in the analysis performed in this section is that we will use the same 10 year sample plan prior to retirement for both preand post-reform periods. This means that we employ the sample of individuals retiring in 1993 to obtain the effect under the pre-reform period, and individuals retiring in 2003 to reveal the effect under the post-reform period.

\subsection{Set-up of the analysis}

Individuals in an earnings based pension system know that their pension level is related to their earnings, and know that if they increase their earnings during the eligible period this will have an impact on the final pension level. So, if there is a response to the social security tax, it can be detected by comparing the old reference period, meaning the last 10 years of earnings, in the pre-reform and post-reform regimes. However, making this comparison fails to control for aggregate changes due to macroeconomic trends or shocks, in particular, wage trends.

A feasible solution to this problem is to use prime-age male individuals' earnings as a control. The sample of prime age individuals group is constructed in the following way. We select them if they are between 35 and 45 in the year 1993 and 2003. These are the same years of retirement of the retired workers. After we identify them we add information on their wages for the previous 10 years. This design of the sample allows us to have individuals in a given year with different ages (age effect), and it allows us to have individuals with the same age in different years (calendar year effect).

In this exercise the goal is to observe how individuals respond to the policy. It is interesting to know if the highest earnings are concentrated in the last years prior to retirement or if they start changing at the beginning of the eligible period.

To evaluate the effect of the policy change we estimate the following specification:

$$
Y_{i, t}=\lambda_{t}+\theta \text { ret }_{i, t}+\alpha \text { post }_{t} \text { ret }_{i, t}+\beta X_{i, t}+\epsilon_{i, t}
$$

The dependent variable $Y_{i, t}$, represents alternately the base wage, total earnings, hourly earnings, and total hours for individual $i$ in the period from 1984 to 2003. ret $_{i, t}$ is an indicator for an individual $i$ retiring (in 1993 or 2003). post $_{t}$ is an indicator for the post-reform period, 1994-2003. post $_{t}$ ret $_{i, t}$ is the indicator for the individual that retires in 2003. $X_{i, t}$ is a set of characteristics of the worker (age, tenure, and education) and the firm where he works (firm size and industry), and $\lambda_{t}$ represents the conventional calendar year fixed effects, while $\epsilon_{i, t}$ is an error term. 
The parameter of interest is $\alpha$, which measures for each labor market outcome the reaction prior to retirement in the post-reform period in comparison with the pre-reform period, after withdrawing the effect of prime-age earnings profile. Under the null hypothesis that the policy change does not affect earnings near retirement, $\alpha=0$. There is a policy effect if $\alpha>0$, which indicates that individuals have increased their capability to command higher earnings near retirement.

\subsection{Preliminary evidence}

In Figure 4 we contrast the age-earnings profiles of prime-age and retiring workers in the pre-reform and post-reform periods. In both periods wages increase at higher rates for prime-age individuals as is expected from ageearnings profile where earnings increase at decreasing rates. This is the reason why the gap between retiring and prime-age workers decreases over time (panel a)). It is worth noting that after the pension reform the earnings of retiring workers declined at a much slower pace in comparison with the pre-reform period. This outcome, that is, the change in the earnings profile approaching retirement (in relative terms), is more clearly shown in panel b), which lies behind the regression model to be presented below. Accordingly, a positive increasing profile throughout the 10 years prior to retirement, most notably in the last 4 years prior to retirement, is shown in the same panel.

\subsection{Discussion of the regression results}

To analyze the impact of pension reform on chosen labor market outcomes we compare the behavior of individuals in the last 10 years prior to retirement in the post-reform period with that in the pre-reform period, after accounting for the evolution observed for prime-age workers. First, we examine the change in retiring workers' real total earnings relative to prime-age workers' real total earnings, in both the pre-reform and post-reform periods. Table 3 reports the regression estimates of the parameters of equation (1). ${ }^{9}$ We shall use different labor market outcome measures, such as base wage (column 1), total earnings (column 2), hourly earnings (column 3), and total hours (column 4). The conventional determinants of wages in the Mincer functions have been considered: schooling, age, tenure, firm size, and industry indicators. We include here a brief discussion of the relevance of including these controls. Theory dictates that the rate of return to education is positive at a diminishing rate per incremental year of schooling (Becker (1993)). Earnings generally rise with age at a

\footnotetext{
${ }^{9}$ However, if wages affect the retirement decision, reverse causality may be an issue. Fortin et al. (2011) suggest that in the presence of two groups A and B even if there is a reverse causality problem, the difference in difference should solve the problem as long as the correlation is the same between the two groups. Although it seems plausible to believe that this would be the case in the present study there could be a simultaneous decision being made due to the policy change.
} 
Figure 4: Changes in the age-earnings profiles (pre-reform versus post-reform)

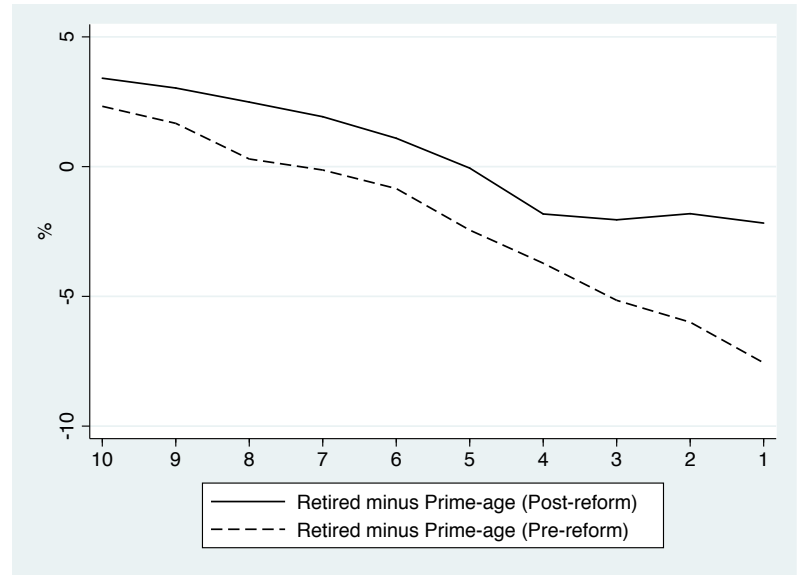

(a) Real total earnings age-gap in the last 10 years

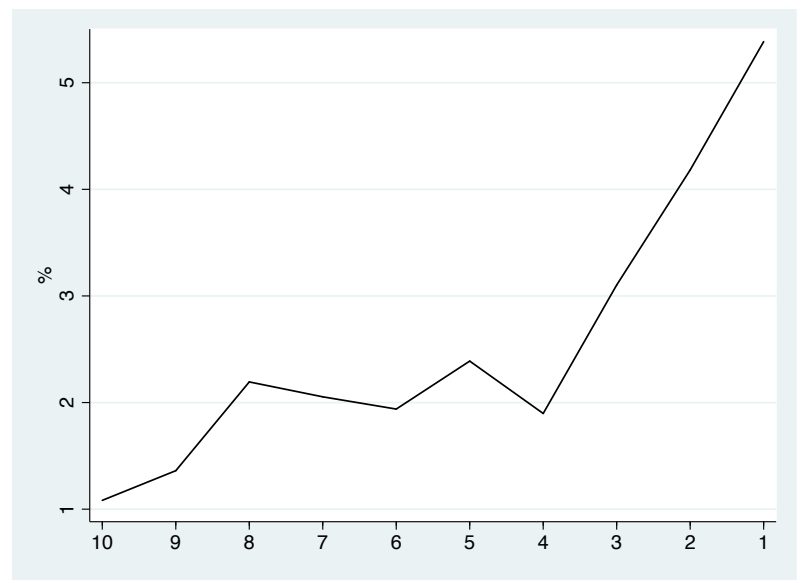

(b) Real total earnings change

Notes: This figure shows in panel a) the difference (in percentage points) between retiring workers' real total earnings in the last 10 years prior to retirement and prime-age workers' real total earnings. The pre-reform period (post-reform period) difference is shown in the dashed line (bold line). In panel $b$ ) this figure shows the vertical distance (in percentage points) between the two lines exhibited in panel a). In both panels, on the horizontal axis, "10" represent the first year of the 10 years, respectively 1984 and 1994 .

decreasing rate and it is expectable that earnings increase with tenure. There are different reasons to expect this effect of tenure on earnings. This effect might be due to on-the-job specific training investment or to the job match hypothesis, meaning that individuals who remain with a firm for a long period are those who have found a job which matches their interests. It is generally found that large firms pay more for equivalent workers than do small firms (Oi and Idson (1999)). The inter-industry wage differentials that exist among 
comparable workers have long been documented (see for example, Krueger and Summers (1988)). 


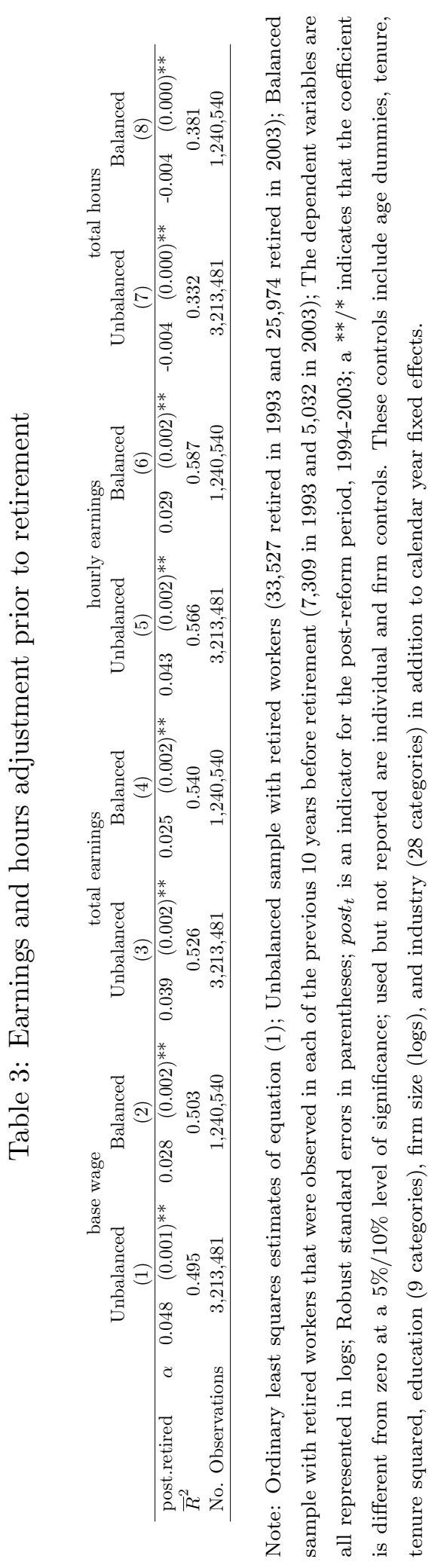


The coefficient estimate $\hat{\alpha}$ is positive for all earnings outcome measures. Retiring workers' real earnings in the last 10 years prior to retirement increased in the post-reform period. Workers observe different patterns of employment during the survey period. To account for compositional changes in the period prior to retirement we also provide regression results for a balanced sample, that is, for workers that are observed during all of the 10 years prior to retirement. Their base wages increase by $4.8 \%$ (2.8\% for the balanced sample) and monthly and hourly earnings by $3.9 \%$ (2.5\% for the balanced sample) in comparison with the pre-reform period. Total hours have decreased but the size of the effect is very small (-0.4\%). ${ }^{10}$ This suggests that individuals did not significantly change their labor supply in terms of hours but their earnings increased, and therefore it can be tentatively taken as evidence of a reaction to the improvement of the tax-benefit link. ${ }^{11}$

In order to reveal the time profile of the effect throughout the 10 years prior to retirement we adapt equation (1) by splitting the coefficient $\alpha$ into 10 coefficients given by $\alpha_{j}$. To evaluate the effect of the policy change we estimate the following specification:

$$
Y_{i, t}=\lambda_{t}+\beta X_{i, t}+\sum_{j=1}^{10}\left(\theta_{j} \text { ret }_{i, j}+\alpha_{j} \text { post }_{t} r e t_{i, j}\right)+\epsilon_{i, t}
$$

post $_{j}$ is a time dummy for each of the 10 years in the post-reform period and post $_{t} r e t_{i, j}$ is therefore the indicator for each of the 10 years prior to retirement for the individual retiring in 2003. The parameters of interest are $\alpha_{j}$, which measure, for each labor market outcome, the reaction for each of the last 10 years prior to retirement in the post-reform period in comparison with the pre-reform period, after deleting the effect of prime-age earnings profile. For example, $\alpha_{1}$ and $\alpha_{10}$ represent the effect 1 and 10 years away from retirement, respectively. Table 4 shows a summary of the results from $\alpha_{j}$ (equation (2)) again using different labor market outcome measures.

Under our identifying assumptions the new pension policy had the following impacts. Retiring workers' real total earnings relative to prime-age workers' real total earnings have increased and there is a clear increasing pattern over the last 10 years prior to retirement. Retiring workers' real base wage 10 years prior to retirement increased $1.6 \%$ and it continued increasing, and in the last year prior to retirement the base wage increased $7.4 \%$. The pattern for total earnings and hourly earnings are in line with the base wage results. In sum,

\footnotetext{
${ }^{10}$ Working hours in Portugal are defined by collective agreements and hours legislation. Thus, the fact that we do not find any hours effect is not unexpected. The $4.1 \%$ reduction of hours for post coefficient is consistent with the results found by Raposo and Van Ours (2010). This study finds that for workers who were affected by the new law, working hours decreased.

${ }^{11}$ Promotions can be taken as indirect evidence of an increase of the workers' effort. Retiring workers' promotions in the last 10 years prior to retirement increased 3.1 percentage points in the post-reform period.
} 
there is evidence that earnings increased especially close to the end of the period prior to retirement, indicating a concentration effect in the last years prior to retirement. With some reservation we offer the tentative explanation that this increasing pattern is the result of procrastination. Individuals postponed the decision to start making an effort to increase their earnings, but once they start, they do it at an increasing rate. This is consistent with the suggestion given by Madrian and Shea (2001) that individuals often post pone their decision to start saving for retirement. However, the same authors find evidence suggesting that once they start saving, they save at an increasing rate. In any case, the accumulated effect over the 10 year period is quite substantial, reaching $41.1 \%$.

In the post-reform period, total hours of retiring workers present a different pattern but the effects are very small. We find no clear pattern for hours. Retiring workers' total hours 10 years prior to retirement remained constant, and then in the last year prior to retirement their total hours decreased $0.5 \%$ ( $0.3 \%$ for the balanced sample). This represents a clear decreasing pattern in the last 10 years prior to retirement, although the size of the effect is very small. This result is interesting because it reveals a mild decreasing pattern in hours worked along with an increasing rising pattern of retiring workers' real earnings. 


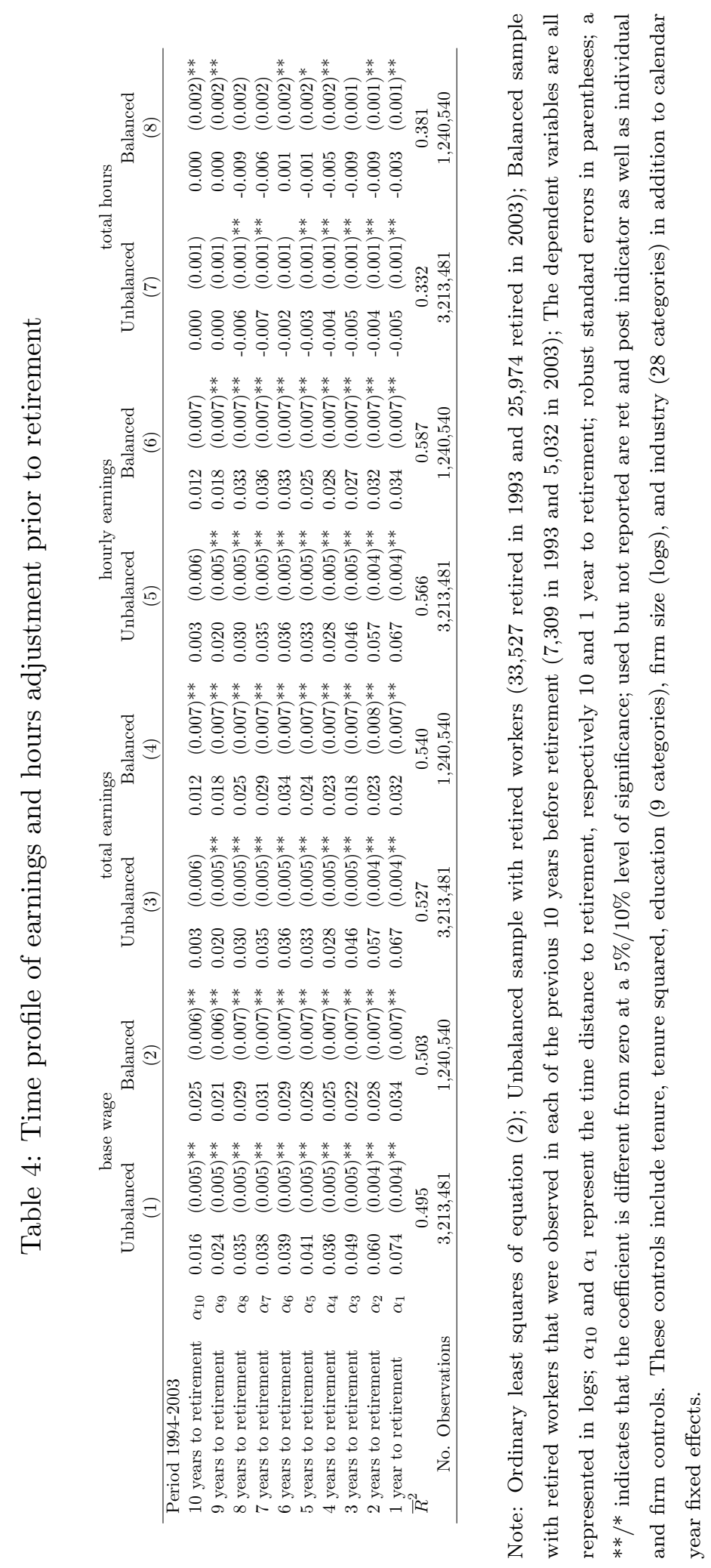




\subsection{Sensitivity analysis}

To further check the adequacy of the procedures used to perform this policy analysis, we undertake a sensitivity analysis, as explained below.

\subsubsection{Sensitivity to age of retirement}

It is reasonable to expect that the individual near retirement is more worried about the conditions of retirement, namely about the age of retirement and about the level of pension he will be entitled to receive. In the previous analysis we do not distinguish between the individual who retires before the age of 65 , from the one who waits to retire exactly at that age.

The individual who retires at 55 might have different characteristics than the individual retiring at 65 , but more importantly, these differences may also influence the labor supply decisions prior to retirement, as well as before that. In Table 5 the results of a sensitivity analysis are reported, distinguishing two distinct moments of retirement: first, individuals who retire between 55 and 60 years old; and second, those who retire between 61 and 65 years old.

Results shown in Table 5 are consistent with the baseline results. There is evidence that both those that retire between 55 and 60 and those that retire between 61 and 65 have increased their earnings, in comparison with the prereform period.

Retired workers aged between 55 and 60 (and also aged between 61 and 65 ) had an increase in their real base wage of around $5 \%$ (3\% for the balanced sample). The pattern for total earnings and hourly earnings are in line with the base wage results.

As expected, there are some differences in terms of magnitude and statistical significance, but in general we conclude that the age of retirement does not appear to seriously alter the effects of the policy change.

\subsubsection{Sensitivity to period following the reform}

The design of the experiment is limited to the period before the reform, because the data set Quadros de Pessoal is available only from 1984 on. Nevertheless, there are no such year constraints in the post-reform period.

In 2002 a new reform in the social security scheme (Decreto-lei 35/2002) was introduced in order to mitigate the persisting financial problems. This law introduced a new formula for calculating the value of retirement pensions. ${ }^{12}$ However, given a transition period, this 2002 reform affects only individuals

\footnotetext{
${ }^{12}$ With the 2002 reform, pensions are calculated using the whole contributive career (instead of the best 10 out of the last 15 years) or the best 40 years when the contributive career is longer. At the same time, this law sets out different accrual rates depending on the workers' compensation (the higher the compensation, the lower the marginal rate, varying between 2.3 and 2 percent) and on career length.
} 
who start working in 2002 or who retire after $2016 .{ }^{13}$ Nevertheless, we can use the years between 2004 and 2006 to check if the chosen period after the policy (1994-2003) is too specific.

In Table 6 it is possible to see that the benchmark results are not greatly changed. The magnitude of $\alpha$ increases between 2003 and 2006 for the three earnings measures. Retired workers' (in 2004) real base wage increased $6.0 \%$ ( $5 \%$ for the balanced sample). Retired workers' total hours (in 2006), decreased at a similar magnitude, in the last 10 years prior to retirement hours decreased on average $-0.7 \%$.

Overall, although there are some differences in the results when different years of retirement are considered, the broad conclusions of the baseline results remain qualitatively the same.

\footnotetext{
${ }^{13}$ Given the significant impact of the new formula, the 2002 law established a transition period, according to the age of individuals at the end of 2001. Individuals 50 to 65 years old on December 31 2001, who are entitled to retirement between January 12002 and December 31 2016, can choose the highest pension. In principle, they choose the pension calculated according to the 1994 rules. Individuals who retire only after December 312016 have their pensions calculated as a weighted average between the pension from the last regime and from the new regime, where the weights correspond to the number of years of service before and after December 312001.
} 


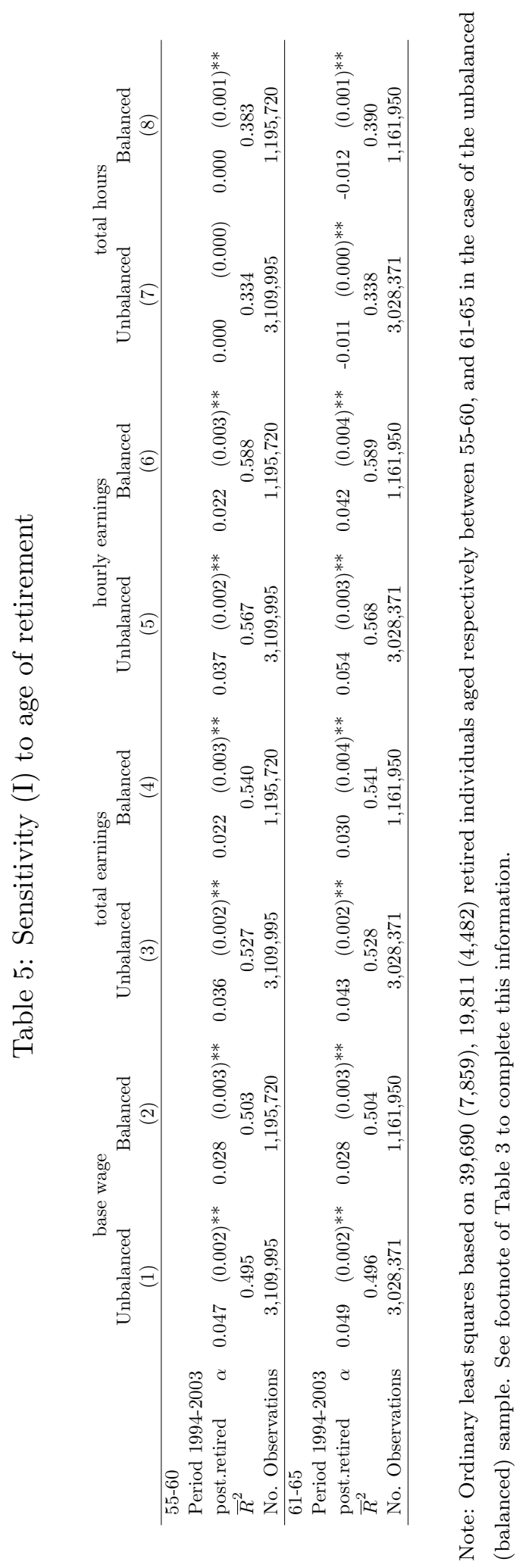




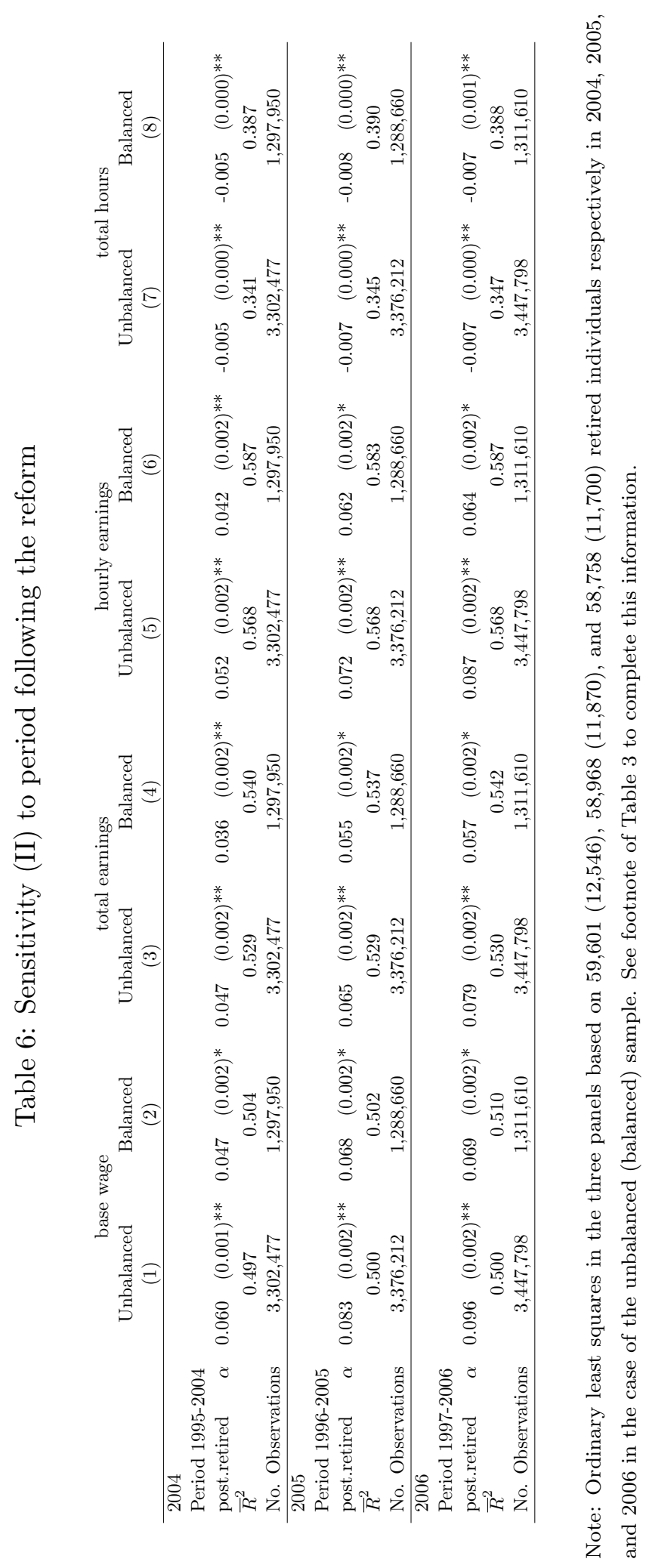




\section{Conclusions}

On January 1st 1994 new legislation introduced two important changes in the Portuguese social security system. First, and very important, there was a change from inflation non-indexed earnings based to inflation indexed pensions earnings based. The second change is related to the enlargement of the eligible period. Specifically, Portugal changed the reference earnings used to calculate the pension into the highest 10 annual labor earnings (in real terms) out of the last 15 , instead of the highest 5 out of the last 10 years (in nominal terms).

We find evidence for a strong positive effect of the policy change on the distribution of pensions. Overall, between 1993 and 2008 pensions increased in real terms by $61 \%$ on average. About half of this increase is generated by the overall wage trend during this period. Indexation explains almost all of the remaining change $(28 \%)$. Indexation also made the amount of the pension significantly more predictable.

Labor earnings increased significantly more in the years close to retirement. Overall, labor earnings moved up by $4.8 \%$ on average over the 10 year eligible period, a notable policy effect. Three mechanisms leading to wage increase may be at work: promotions; collusion between firms and workers; and the operation of deferred compensation schemes. The effect on earnings is partly explained by an increase in the incidence of promotions. We interpret this as evidence that individuals reacted to a policy change that altered the link between contributions and benefits.

The time pattern of wage increases is also notable. Greater wage hikes are observed closer to retirement age. We can only speculate about the reason why the effect is especially large for the last 4 years prior to retirement. We offer the tentative explanation that this increasing pattern is the result of procrastination and collusion.

Our interpretation of these findings is that reforms that change the taxbenefit link should pay special attention to the labor supply responses of the workers.

\section{References}

Becker, G. (1993). Human capital: a theoretical and empirical analysis, with special reference to education. National Bureau of Economic Research. The University of Chicago Press.

Benartzi, S. and Thaler, R. (2007). Heuristics and biases in retirement savings behavior. Journal of Economic Perspectives, 21(3):81-104.

Blöndal, S. and Scarpetta, S. (1999). The retirement decision in OECD countries. OECD Economics Department Working Papers 202, OECD, Economics Department. 
Boeri, T., Börsch-Supan, A., and Tabellini, G. (2001). Would you like to shrink the welfare state? A survey of European citizens. Economic Policy, 16(32):7-50.

Boeri, T. and Van Ours, J. C. (2008). The Economics of Imperfect Labor Markets. Princeton University Press.

Cardoso, A. R. (2006). Wage mobility: Do institutions make a difference? A replication study comparing Portugal and the UK. Labour Economics, 13(3):387-404.

Cardoso, A. R. and Portugal, P. (2005). Contractual wages and the wage cushion under different bargaining settings. Journal of Labor Economics, $23(4): 875-874$.

Chan, S. and Stevens, A. H. (2008). What you don't know can't help you: Pension knowledge and retirement decision-making. The Review of Economics and Statistics, 90(2):253-266.

Disney, R. (2004). Are contributions to public pension programmes a tax on employment? Economic Policy, 19(39):267-311.

Disney, R. and Smith, S. (2002). The labour supply effect of the abolition of the earnings rule for older workers in the United Kingdom. Economic Journal, 112(478):C136-C152.

Dominitz, J., Manski, C., and Heinz, J. (2003). Will social security be there for you?: How Americans perceive their benefits. NBER Working Papers 9798, National Bureau of Economic Research, Inc.

Feldstein, M. (2005). Rethinking social insurance. American Economic Review, 95(1):1-24.

Fisher, W. and Keuschnigg, C. (2010). Pension reform and labor market incentives. Journal of Population Economics, 23(2):769-803.

Fortin, N., Lemieux, T., and Firpo, S. (2011). Decomposition Methods in Economics, volume 4 of Handbook of Labor Economics, chapter 1, pages 1-102. Elsevier.

Gruber, J. and Wise, D. (2004). Social Security Programs and Retirement around the World: Micro-Estimation. NBER Books. National Bureau of Economic Research, Inc.

Keuschnigg, C. and Keuschnigg, M. (2004). Aging, labor markets, and pension reform in Austria. FinanzArchiv: Public Finance Analysis, 60(3):359-392.

Krueger, A. B. and Summers, L. H. (1988). Efficiency wages and the interindustry wage structure. Econometrica, 56(2):pp. 259-293. 
Lazear, E. (1998). Personnel economics for managers. Wiley.

Liebman, J., Luttmer, E., and Seif, D. (2009). Labor supply responses to marginal social security benefits: Evidence from discontinuities. Journal of Public Economics, 93(11-12):1208-1223.

Lynch Jr., J. and Zauberman, G. (2006). When do you want it? Time, decisions, and public policy. Journal of Public Policy $\&$ Marketing, 25(1):67-78.

Madrian, B. and Shea, D. (2001). The power of suggestion: Inertia in 401(k) participation and savings behavior. The Quarterly Journal of Economics, 116(4):1149-1187.

Martins, P., Novo, A., and Portugal, P. (2009). Increasing the legal retirement age: The impact on wages, worker flows and firm performance. IZA Discussion Papers 4187.

O'Donoghue, T. and Rabin, M. (2001). Choice and procrastination. The Quarterly Journal of Economics, 116(1):121-160.

OECD (2001). OECD economic surveys: Portugal 2001.

Oi, W. Y. and Idson, T. L. (1999). Firm size and wages. In Ashenfelter, O. and Card, D., editors, Handbook of Labor Economics, volume 3 of Handbook of Labor Economics, chapter 33, pages 2165-2214. Elsevier.

Raposo, P. S. and Van Ours, J. C. (2010). How working time reduction affects jobs and wages. Economics Letters, 106(1):61-63. 


\section{Appendices}

\section{Appendix A - Description of variables}

Pension: Refers to the retirement pension. It is the monthly amount calculated on accrued seniority at retirement, which is a weighted average of the labor earnings obtained throughout a period in the person's working career. It is calculated according to the pre- and post-reform rules (own calculations).

Retired worker: A worker is considered to be retired if he is over 55 years old, he exits the sample, and does not return to the employer-employee matched database.

Firm closure: A firm closure is observed if the identification number of one firm appeared in period $t$ but did not appear in $t+1, t+2$, and $t+3$.

Base wage: Labor earnings that are fixed and paid regularly on a monthly basis.

Total earnings: Labor earnings that are a combination of several components: base wage, regular payments (e.g., seniority and transportation), irregular benefits (profits and premia), and overtime hours payments.

Normal hours: Actual hours during a normal week at the going wage.

Overtime hours: Time worked in a week at an overtime premium $(50 \%$ for the first hour, $75 \%$ for additional hours).

Total hours: Sum of normal and overtime hours.

Hourly earnings: Ratio between total earnings and total hours.

Promotion: Identified by the reported date of the last promotion in that year. Promotion is a categorical variable equaling one if the individual had a promotion in the last 12 months.

Tenure: Duration measured in years of current job or contract.

Age: Age of the individual measured in years.

Prime-age workers: workers aged between 35 and 45 .

Education level: Seven education categories were defined: (1) Less than Ba- 
sic School, which includes individuals with fewer than 4 years of schooling, (2) Basic School, which includes individuals with 4 completed years of schooling, (3) Preparatory, which includes individuals with 6 completed years of schooling, (4) Lower Secondary, which includes individuals with fewer than 10 years but more than 6 completed years of schooling, (5) Upper Secondary, which includes individuals with secondary schooling, (6) College, which includes individuals with at least a bachelor degree, and (7) undefined category, for the individuals with an undefined level of education.

Firm size: The number of workers currently working in the firm, measured in logarithm.

Industry: Six categories were defined: (1)Manufacturing, (2)Construction, (3)Commerce, (4)Transports, (5)Financial, and (6)Education/Health. 


\section{Appendix B - Descriptive statistics}

\begin{tabular}{|c|c|c|c|c|}
\hline & \multicolumn{2}{|c|}{ Non-retired workers } & \multicolumn{2}{|c|}{ Retired workers } \\
\hline & 1993 & 2003 & 1993 & 2003 \\
\hline & (1) & (2) & (3) & (4) \\
\hline Base wage (real euros) & 245.69 & 289.60 & 243.84 & 292.93 \\
\hline Monthly earnings (real euros) & 294.54 & 353.14 & 289.04 & 355.33 \\
\hline Hourly earnings (real euros) & 1.67 & 2.07 & 1.62 & 2.05 \\
\hline Total hours (per week) & 41.74 & 39.98 & 42.34 & 40.40 \\
\hline Normal hours (per week) & 41.15 & 39.39 & 41.81 & 39.62 \\
\hline Overtime hours (per week) & 0.59 & 0.58 & 0.53 & 0.78 \\
\hline Promotion (percentage 1-100) & 13.80 & 12.14 & 8.19 & 8.42 \\
\hline Tenure (years) & 10.50 & 8.73 & 18.09 & 16.35 \\
\hline Age (years) & 36.57 & 36.52 & 55.81 & 55.44 \\
\hline \multicolumn{5}{|l|}{ Education: } \\
\hline Less than Basic School & 2.91 & 1.57 & 17.62 & 5.56 \\
\hline Basic School & 53.95 & 33.23 & 58.63 & 64.54 \\
\hline Preparatory & 12.54 & 24.43 & 6.61 & 10.39 \\
\hline Lower Secondary & 8.51 & 16.23 & 3.83 & 9.69 \\
\hline Upper Secondary & 14.85 & 16.30 & 7.73 & 4.45 \\
\hline College & 4.52 & 6.80 & 2.88 & 3.99 \\
\hline Undefined & 2.72 & 1.44 & 2.70 & 1.38 \\
\hline Firm size (no.-workers) & 2091 & 827 & 1849 & 802 \\
\hline \multicolumn{5}{|l|}{ Industry: } \\
\hline Manufacturing & 47.15 & 36.87 & 48.97 & 39.44 \\
\hline Construction & 8.89 & 15.70 & 12.40 & 14.30 \\
\hline Commerce & 19.61 & 24.55 & 19.00 & 21.51 \\
\hline Transports & 11.64 & 8.97 & 13.68 & 14.58 \\
\hline Financial services (except banks) & 3.63 & 5.78 & 3.43 & 5.95 \\
\hline Education/Health & 1.76 & 3.83 & 2.52 & 4.22 \\
\hline Banking services & 7.32 & 4.30 & & \\
\hline No. Observations & $1,358,802$ & $1,566,083$ & 165,292 & 123,304 \\
\hline
\end{tabular}

Notes: This table reports summary statistics (mean) for 1993 and 2003, the two base years used in the analysis. Columns (1) to (3) are statistics computed using non-retired male workers and columns (3) to (5) are computed using the sample of male workers who retired in the given years. Variables represented are those described in detail in Appendix A. The units are explained in front of the variables, while Education and Industry are shown as a percentage. 


\section{Appendix C - Wage setting in Portugal}

Portugal is considered to have a regulated labor market, with minimum wages, strong employment protection, and collective bargaining widely applied (OECD (2001) and Cardoso (2006)). In the 1990s Portugal was characterized by low unemployment rates, approximately 3-4 percentage points below the EU-15 average. In 1994 the minimum legal monthly wage was 246 euros. The mandatory minimum wage represented around $37 \%$ of the median total monthly earnings of full-time employees (Eurostat). ${ }^{14}$

Concerning the bargaining mechanisms, the Portuguese collective bargaining regime calls for direct negotiation between unions and employers' associations, establishing the minimum conditions of the base wage for each job title, the normal hours of work, and overtime pay. Collective agreements are typically updated annually. Most of those are settled at the industry level, but there are also firm-level agreements. Even though industry collective bargaining is clearly predominant in Portugal, firm-level bargaining, more common in large public companies, affects only $3 \%$ of the workers.

Since the Portuguese government often decides to extend collective agreements to workers not covered, the impact of collective bargaining reaches more than the union members. In this sense, the impact of collective bargaining on a given worker or firm is essentially unrelated to the fact of the worker being a member of a union or not, or the firm belonging to an employer association. In fact, firms can offer better conditions than those established by the collective agreement. In particular, they can pay higher wages to their workers. Cardoso and Portugal (2005) call this the "wage cushion", the difference between the contractual part of the wage and the actual wage. They estimate that in 1999 actual wages exceeded the level of bargained wages by $20-50 \%$.

\footnotetext{
${ }^{14}$ Minimum wage is updated every year by government proposal, taking into account inflation and GDP growth as well as the labor unions' expectations.
} 